\title{
HUDEBNÍ VĚDA V BRNĚ PO ROCE 1989
}

Brněnské hudebněvědné instituce reprezentované vzdělávacími, vědeckými či vědecko-dokumentačními pracovišti patří bezesporu $\mathrm{k}$ hlavním piliřům české muzikologie. Od svého založení prošly dlouhým vývojem, v tomto př́íspěvku se zaměříme zejména na jejich aktivity v období od roku 1990 do současnosti.

Začít musíme samožrejmě institucí oborově nejvýznamnější, a to Ústavem hudební vědy Filozofické fakulty Masarykovy univerzity. Po společenských změnách konce roku 1989 se ujal vedení tehdejší Katedry věd o umění Jiří Fukač a po dvou letech společného působení s divadelní vědou a kunsthistorií se hudební věda osamostatnila v Ústav hudební vědy. Personální složení ústavu se začalo postupně proměňovat, z původního týmu ve složení Jiří Vysloužil, Rudolf Pečman, Jiří Fukač, Miloš Štědroň, Olga Settari odešla Olga Settari a po konkurzním řízení přišel na její místo organolog Pavel Kurfürst. Znatelně se rozšiříil počet externích vyučujících (mj. Stanislav Tesař, Jiří Sehnal, Ivan Poledňák, Eva Drlíková, Vladimír Karbusický, Jan Trojan, Pavel Sýkora ad.). Změnou politického systému se vzápětí uvolnila pedagogům hudební vědy zasloužená cesta ke zvyšování akademických hodností (Pečman: profesor 1990; Fukač: docent 1991, profesor 1994; Štědroň: docent 1991, profesor 1994; Kurfürst: docent 1994, profesor 1999). Př́chodem zástupců tehdejší nejmladší muzikologické generace, kteří byli odchováni brněnskou hudební vědou (Jana Perutková - Dvořáková: 1996; Petr Macek: 1995; Mikuláš Bek: 1998; Lubomír Spurný: 2003) byly dány předpoklady pro další plynulý rozvoj brněnské univerzitní muzikologie. Součástí ústavu se od začátku 90. let stala Akademie staré hudby s nově ustaveným bakalářským oborem Studium teorie a provozovací praxe staré hudby, u jejího zrodu stál zejména Andreas Kröper-Hoffmann, a Seminář estetiky, reprezentovaný Jaroslavem Stř́teckým a Petrem Osolsobě (od ledna roku 2005 se toto pracoviště v rámci fakulty osamostatnilo, Jaroslav Střítecký zůstal kmenově na Ústavu hudební vědy).

$\mathrm{V}$ průběhu let pedagogové ústavu aktivně vstupovali a vstupují do akademických a řídících funkcí, Pečman se stal proděkanem pro studium, Štědroň proděkanem pro vědu a výzkum, Fukač předsedou Akademického senátu Filozofické fakulty MU. V roce 1998 se pak stal Jiří Fukač prorektorem Masarykovy univerzity, vedení ústavu přebral Stanislav Tesar̆, který po roce předal funkci vedoucího 
Mikuláši Bekovi. Po pěti letech, v roce 2004 se stal Bek prorektorem pro vnější vztahy Masarykovy univerzity a následně v roce 2011 rektorem. Od podzimu roku 2004 až do současnosti je vedoucím ústavu Petr Macek.

Během tohoto období došlo k významnému rozmachu ústavu jak po stránce personální, tak i pedagogicko-organizační, postupně byly akreditovány další studijní obory, k Hudební vědě, Teorii a provozovací praxi staré hudby a Sdruženým uměnovědným studiím, akreditovaným v polovině 90 . let, přibyla ještě Teorie interaktivních médií, Učitelství estetické výchovy pro střední školy, Management v kultuře a Srovnávací uměnovědná studia. Na ústavu studuje cca 1500 studentů, $\mathrm{z}$ toho $50 \mathrm{v}$ doktorském programu. Kromě zajištění kvalitní pedagogické výuky a odpovídajícího zázemí je kladen v Brně velký důraz i na propojení teoretické části s praktickou, všichni studenti prochází v každém cyklu studia povinnou praxí v odborných institucích (muzea, filharmonie, divadlo, televize apod.), studenti jsou vedeni $\mathrm{k}$ vědecké práci pořádáním pravidelných výjezdních studentských konferencí, každoročně je organizováno několik specializovaných domácích i zahraničních muzikologických exkurzí (např. do Moskvy, Petrohradu, Londýna, Paříže, Berlína atd.), sounáležitost $\mathrm{k}$ ústavu je utvrzována i pořádáním různých společenských celoústavních akcí. Pod Ústavem hudební vědy působí studentský Symfonický orchestr Masarykovy univerzity, mužský a smíšený sbor, studenti jsou vedeni k praktickému muzicírování v rámci Collegia musica či předmětu Hra na klavír.

Konstatujme, že posluchači Ústavu hudební vědy velmi aktivně spolupracují na jednotlivých vědeckých projektech ústavu, publikují v odborných časopisech a zapojují se do kulturního života Brna i České republiky, důkazem dané úrovně je napríklad časté umístění na prvních či vrcholových pozicích v soutěži České společnosti pro hudební vědu o nejlepší odbornou studentskou práci. Absolventi nachází uplatnění nejen v akademické, vědecké a pedagogické sfére, ale i na řídících místech filharmonií, divadel, rozhlasu a televizí.

Ústav zaměstnává celkem 20 pracovníků, včetně vědeckých a administrativních. V plném pracovním úvazku jsou dva profesoři, Miloš Štědroň a Jaroslav Střítecký, posilou je také stále emeritní profesor Jiří Vysloužil. Pedagogický a vědecký chod pracoviště dále zajišt'ují čtyři docenti, a to Mikuláš Bek, Jana Horáková, Jana Perutková a Lubomír Spurný, dále pak odborní asistenti a asistenti, jmenovitě muzikologové Vladimír Maňas, Jiří Zahrádka, Stanislav Tesař, Aleš Opekar, Petr Macek, Martin Flašar, Jozef Cseres, Viktor Pantůček, Jan Špaček a Robert Hugo (pro ASH), z kunsthistoriků Aleš Filip a Dagmar Koudelková. Odborným pracovníkem je Petr Kalina a Šárka Zahrádková, knihovnu vede Jan Karafiát a Ludmila Němcová.

Vědecké zaměření ústavu sledovaného období je spojeno zejména s projekty Centra hudební lexikografie při ÚHV FF MU, v roce 1997 vyšel po dlouhém úsilí Slovník české hudebni kultury, od roku 2000 pak byl zahájen nový projekt elektronického Českého hudebního slovníku osob a instituci na webové adrese www. ceskyhudebnislovnik.cz. Miloš Štědroň publikoval práci Leoš Janáček a hudba 20. století, Pavel Kurfürst je autorem dvou stěžejních knižních prací, a to Organologie (propedeutika, exemplifikace) a Hudebni nástroje. Jiří Vysloužil vydal mimo jiné 
monografii o Karlu Husovi či spolu s Jiř́m Sehnalem Dějiny hudby na Moravě, Mikuláš Bek publikoval své sociologické výzkumy v práci Konzervatoř Evropy? $K$ sociologii české hudebnosti, Rudolf Pečman sepsal monografii o Vladimíru Helfertovi. Stanislav Tesař pracoval na rozsáhlém grantovém projektu Melodiarum Hymnologicum Bohemiae, Jana Perutková vydala monografii o Františku Antonínu Míčovi a jaroměřické opeře, Lubomír Spurný publikoval spolu s Vlastou Reittererovou práce k životu a dílu Aloise Háby, Jiř́i Zahrádka vydává edice díla Leoše Janáčka, Viktor Pantůček s mladšími kolegy pokračuje na dokumentaci české hudební kultury druhé poloviny 20 . století a tak dále a tak dále.

$S$ vědeckou činností souvisí i získávání grantových prostředků na její realizaci, během sledovaného období ústav řešil prostřednictvím svých pracovníků desítky grantových projektů, zejména Grantové agentury České republiky, Ministerstva kultury a Ministerstva školství.

Ústav hudební vědy vydává recenzovaný časopis Musicologica Brunensia, provozuje také studentský on-line časopis Musicologica.cz. Tradiční je pořadatelství Mezinárodních hudebněvědných kolokvií.

Po roce 1989 navázala brněnská univerzitní hudební věda velmi úzkou spolupráci (zejména díky Jiřímu Fukačovi) se zahraničními partnery, zvláště s Institutem hudební vědy vídeňské univerzity, od roku 1991 byl vydáván dokonce společný česko-německý Bulletin pro muzikologickou spolupráci Colloquium danubianum. Intenzívní spolupráce probíhala také se Sudetoněmeckým institutem v Řezně, mj. na projektu Lexikon zur deutschen Musikkultur. V druhé polovině 90. let sídlila na ústavu také česká sekce Mezinárodní asociace pro výzkum populární hudby (IASPM), které předsedal Jiří Fukač.

Brněnský Ústav hudební vědy se stal v letech 1994 - 1998 spolupartnerem projektu TEMPUS, $v$ jehož rámci se uskutečnila celá řada velmi užitečných odborných studentských seminářŭ, bylo vydáno několik knih a studentům i pedagogům bylo sjednáno mnoho zahraničních pobytů. Od roku 2000 je Ústav hudební vědy součástí mezinárodního vzdělávacího programu Evropské unie Socrates/ Erasmus, studenti vyjiždí na dlouhodobé stáže na muzikologická pracoviště partnerských univerzit do většiny států Evropy. V letošním akademickém roce vyjelo či vyjede za ústav na tento typ stáží 31 studentů.

Kromě Erasmu je zajišt'ována pro studenty i výuka zahraničními hostujícími profesory. Po dvouletém pedagogickém úvazku Geoffrey Chewa funguje nyní model semestrálních přednáškových pobytů, takto zde působil např́íklad Oskar Elschek či Lubomír Chalupka.

Z podnětu Ústavu hudební vědy se stali čestnými doktory Masarykovy univerzity také muzikologové, a to konkrétně Hans Heinrich Eggebrecht (1995), Theophil Antonicek (2000) a John Tyrrell (2002).

$\mathrm{V}$ polovině 90 . let opustil Ústav hudební vědy svoje dlouholeté působiště ve druhém poschodí hlavní fakultní budovy a po několika dalších stěhováních se v roce 2011 (snad už natrvalo) usídlil v samostatné budově na Janáčkově náměstí 2a.

Velký důraz je dlouhodobě kladen na rozvoj knihovny Ústavu hudební vědy: na nákup muzikologické literatury a odborných elektronických on-line databází 
je vyčleňováno díky získaným grantovým i ústavním prostředkům ročně statisíce korun. Zatímco většina Filozofické fakulty jde cestou rušení dílčích ústavních knihoven a slučováním do jedné knihovny centrální, postup Ústavu hudební vědy je opačný, budování samostatné špičkové knihovny s odborným personálem.

Máme-li shrnout roli brněnského Ústavu hudební vědy v období po roce 1990 do současnosti, konstatujme, že zůstává v celostátním i mezinárodním měřítku důstojným reprezentantem muzikologické instituce v oblasti vědecké i pedagogické.

Muzikologie, zejména ve svých hudebně teoretických, naukově pedagogických a historických disciplínách, se v Brně uplatňuje i na dalších vysokých školách.

Prvním pracovištěm rozvíjejícím takto hudebněvědnou oblast je Katedra hudební výchovy, která je součástí Pedagogické fakulty od jejího vzniku v roce 1946 a za dobu své existence vychovala tisíce kvalifikovaných učitelů hudební výchovy pro všechny typy a stupně škol. Brněnské hudebněvýchovné pracoviště vždy úzce spolupracovalo s univerzitní hudební vědou. V letech 1946-1951 budoval seminář hudební výchovy na mladé pedagogické fakultě ve funkci pověreného profesora Bohumír Štědroň, kterého později vystř́dal František Lýsek. S Lýskem se katedra začala zabývat především problematikou vokální intonace. Lýsek sám spojoval zaměření sbormistrovské a teoretické (zejména v oblasti vývojové hudební psychologie, didaktiky a metodiky hudební výchovy). V takto vymezeném výzkumném směru pokračoval i Lýskův nástupce ve vedení katedry Evžen Valový. I po odchodu Valového na JAMU, kdy vedení katedry převzal varhaník Miloslav Buček, se na pracovišti rozvíjela muzikologická aktivita, zejména péčí Zdeňka Marka, Blanky Bajerové, Leoše Faltuse či Boženy Küfhaberové. V 80. letech na katedře částečně pedagogicky působili i učitelé z Filozofické fakulty, konkrétně Rudolf Pečman a Miloš Štědroň. V 90. letech nahradil Miloslava Bučka ve vedení katedry Michal Košut a následně Vladimír Richter. Vědecká, odborná a publikační aktivita pracovníků katedry je vedle tvorby studijních textů a učebnic zaměřena v posledním období zejména do okruhu problémů hudební sociologie a prostřednictvím konkrétních empirických výzkumů (uved’me především projekt výzkumu hudebních preferencí vysokoškolské mládeže) v celé oblasti hudební výchovy a hudební kultury usiluje o zachycení dynamiky proměn sociálních funkcí hudby v životě mladého člověka. Z pracovníků podílejících se na aktuálních hudebněvědných projektech jmenujme zejména Bedřicha Crhu, Blanku Knopovou, Juditu Kučerovou a Marka Sedláčka.

Významnou aktivitou katedry, jejíž tradice sahá do 60. let dvacátého století, jsou pravidelné mezinárodní hudebně pedagogické konference MUSICA VIVA IN SCHOLA, které volně navazují na aktivity International Society for Music Education a tematicky akcentují vždy aktuální okruhy problémů hudební výchovy.

Druhým vysokoškolským pracovištěm v Brně, které rozvijí mimo jiné i hudebněvědnou oblast, je Hudební fakulta Janáčkovy akademie múzických umění. I zde byly soustředěny nejen významné pedagogické síly, ale i osobnosti, které byly schopny tvůrčí badatelské práce. Muzikologickou autoritu v už raném vývoji školy představoval její první rektor Ludvík Kundera, Helfertův žák, pozdější autor prací o Beethovenových klavírních sonátách či monografie o Václavu Kaprálovi. 
Výzkumné aktivity Hudební fakulty Janáčkovy akademie múzických umění mají své kořeny již v 50. letech 20. století, a to díky Ivanu Vojtěchovi, Františku Hrabalovi a zejména Jiř́mu Vysloužilovi, který zde působil v letech 1953 až 1961. V šedesátých a sedmdesátých letech byl muzikologický profil JAMU určen především činností Josefa Burjanka, později také hudebního historika Jana Trojana a skladatele a hudebního teoretika Ctirada Kohoutka. V oblasti hudební teorie se exponoval také skladatel Alois Piňos. Po roce 1990 se stali hlavními představiteli muzikologické práce zejména Jindra Bártová a Leoš Faltus. Rozsahem nejdůležitějši výzkum probíhal v souvislosti s řešením projektů podpořených vědeckovýzkumnými granty, konkrétně uved'me zejména projekt Janáčkových nápěvků mluvy (hlavní řešitel Monika Bártová Holá), dále Výzkum nových kompozičnich metod: komponováni $v$ hudebnich animačnich programech a $v$ hudebni výchově (řešitel Ivo Medek), stejně jako hudebně ediční projekty spojené s Leošem Janáčkem (Leoš Faltus). Důležitou aktivitou je také pořádání odborných setkávání, především každoročních mezinárodních konferencí Musica Nova, ale i dalších akcí (např́klad konference Evropská mobilita a stará hudba ad.).

$\mathrm{Z}$ dalších institucí se $\mathrm{v}$ Brně částečně zabývá muzikologickou problematikou brněnské pracoviště Etnologického ústavu České akademie věd, které zde bylo založeno už v roce 1954 a jednou z jeho hlavních pracovních oblastí byla od počátku hudební folkloristika, především sběr a katalogizace lidových písní. S historií brněnského pracoviště jsou spojena zejména jména Karla Vetterla a Olgy Hrabalové. Současné folkloristické výzkumy probíhají paralelně se zpracováním a publikováním archivních fondů. Z hlavních kmenových pracovníků jmenujme Martu Toncrovou, Věru Frolcovou, Lucii Uhlíkovou, působila zde také Jarmila Procházková. $Z$ dlouhodobějších a větších projektů pracoviště je potřeba zmínit výzkum Etnokulturnich tradic v současné společnosti, především spojených s využiváním a funkcemi hudebního folkloru a hudebnětanečních aktivit (řšsitel Marta Toncrová), dále projekt zaměřený na stanovení charakteristických znaků obrazu romské a židovské minority v lidových písních z českých zemí a jejich konfrontaci se slovenským materiálem (řrešitelé Marta Toncrová a Lucie Uhlíková), výzkum lidových písní moravského Horňácka včetně edice nepublikovaných písní Martina Zemana (Marta Toncrová a Lucie Uhlíková), dále pak projekt zaměřený na zpracování Janáčkova folklorního materiálu z Moravy, Slezska a Slovenska (Lucie Uhlíková). Pokračuje také vydávání a příprava pramenných a populárně-vědných edic folklóru, nedávno byla např́klad vydána sbírka s názvem Lidové pisně z Podhorácka II. (péčí Marty Toncrové a Silvy Smutné).

Sbírkotvorná, výzkumná a prezentační činnost je náplní poslední hudebněvědné brněnské instituce, a to Oddělení dějin hudby Moravského zemského muzea, které se celkově zaměřuje $\mathrm{k}$ hudební historii Moravy se zvláštním zřetelem $\mathrm{k}$ životu a dílu Leoše Janáčka. Tato ústřední moravská instituce byla založena v roce 1919 Vladimírem Helfertem, od roku 1930 byl jejím vedoucím Jan Racek, od roku 1948 pak Theodora Straková, od roku 1978 až do 90. let pak celé pracoviště výrazně profiloval Jiří Sehnal. Samostatné vědeckovýzkumné práci se kromě uvedených vedoucích pracovníků dále věnovali zvláště Svatava Přibáňo- 
vá, Miloš Štědroň a Vojtěch Kyas. Po penzionování Jiř́ího Sehnala pracoviště postupně vedli Jitka Bajgarová, František Malý, Jiří Zahrádka a v současnosti Simona Šindlářová. Z výzkumných oblastí jmenujme zejména život a dílo Leoše Janáčka (péčí především Jiřího Zahrádky a Libuše Janáčkové), dále probíhal výzkum operních libret 17. - 18. století z moravských hudebních sbírek (v gesci Jany Spáčilové, nyní působící v Olomouci), je studována hudební kultura rodu Magnisů (Simona Šindlářová) či kantorská hudba 18. století (František Malý), z novější historie je zkoumán skladatelský odkaz Aloise Háby, Aloise Piňose, Václava Oborného (Ondřej Pivoda) ad. Činnost Oddělení dějiny hudby byla v posledním období omezena dokončováním rozsáhlé rekonstrukce budovy na Smetanově ulici, přesto zůstává setrvání oddělení ve střednědobém výhledu stále nejisté. Pracoviště bojuje s omezováním stavu odborných pracovníků, v roce 2006 došlo ke snížení systemizovaného stavu na polovinu. Oddělení dějin hudby velmi intenzívně spolupracuje s Ústavem hudební vědy FFMU, personální provázanost i společné grantové projekty (v poslední době zejména projekt GAČR Jiř́iho Zahrádky na zpracování korespondence Leoše Janáčka) dávají i do budoucna předpoklad vzájemné symbiózy obou pracovišt'.

Na základě konstatovaných skutečností se nyní pokusme o stanovení dalších možných perspektiv rozvoje hudební vědy v Brně:

Hudební věda je relativně malý obor. K prosazování společných zájmů a k rozvoji nejen brněnské, ale celé české muzikologie bude nutné ještě výrazně intenzívněji zúžit oborovou spolupráci v linii hudebněvědných kateder Praha Brno Olomouc, ale také s přispěním všech hudebněvýchovných kateder pedagogických fakult a př́slušných kateder vysokých uměleckých škol, Etnologického ústavu Akademie věd a všech odborných dokumentačních pracovišt'. Intenzívnější musí být i spolupráce $\mathrm{v}$ rámci jednotlivých center. Formulování velkých společných vědeckých projektů, př́ípadně i se zapojením zahraničních partnerů ze Slovenska a dalších států, bude nezbytné pro zvýšení úspěšnosti u grantových žádostí všech typů. V poslední době je zřejmé, že podstatně vyšší šanci na úspěch při grantových žádostech mají zejména větší a velké oborové projekty. Přesto společné institucionální grantové žádosti jsou v našem oboru stále spíše výjimečné.

Nutná je i spolupráce v oblasti pedagogického rozvoje, stále více se ukazuje jako užitečné napríklad společné sdílení výuky vybraných předmětů, které nejsou z personálních či odborných důvodů ostatní pracoviště schopná realizovat, přesto by ve studijním plánu neměly chybět. Tento způsob kooperace funguje na Ústavu hudební vědy už radu let $\mathrm{s}$ Janáčkovou akademií múzických umění a v posledních dvou letech i olomouckými partnery v rámci projektu Konsorcia vysokých škol. Užitečné by bylo rozšiřrení této kooperace i na další, zejména pražská pracoviště. Na podobném principu je možné i vzájemné sdílení vedoucích diplomových prací či školitelů a konzultantů pro doktorské studium, stejně jako vytváření celých společných studijních oborů, viz např́íklad už realizovaný společný obor JAMU a Filozofické fakulty MU s názvem Historická interpretace. Užitečné by také byly semestrální výměnné pobyty studentů na partnerských pracovištích v rámci České republiky, jak je to obvyklé při zahraničních stážích, 
což bohužel naráží na problém financování a zatím to ani zcela neumožňuje právní rámec českého vysokoškolského vzdělávání, stejně jako výměnné semestrální hostující přednášky konkrétních pedagogů českých vysokých škol.

Závěrem konstatujme, že směřování brněnské hudební vědy v devadesátých letech 20. století bylo ovlivňováno zejména velmi aktivním, obětavým a činorodým prrístupem Jiř́ho Fukače, jehož odchod v roce 2002 byl nejen pro brněnský Ústav hudební vědy, ale i pro českou muzikologii mimořádně velkou a citelnou ztrátou. Je proto zejména na střední a mladší brněnské muzikologické generaci, aby navázáním na své univerzitní učitele, tedy konkrétně na Jiř́ho Vysloužila, Rudolfa Pečmana, Jiř́ho Fukače a také Miloše Štědroně, pokračovala v tradici dobrého jména brněnské muzikologické školy.

Petr Macek (macek@phil.muni.cz), Ústav hudební vědy, Filozofická fakulta, Masarykova univerzita, Brno.

\section{ABSTRACT \\ MUSICOLOGY IN BRNO AFTER 1989}

The paper examines the situation and scholarly activities of Brno musicology in the last 25 years, follows musicological institutions at universities, especially the Institute od Musicology, Faculty of Arts, Masaryk University, but also the Faculty of Music at the Janáček Academy of Music and Performing Arts and the Faculty of Education at the Masaryk University and summarizes the activities of other significant scholarly, research and documentary institutions (the Brno branch of the The Institute of Ethnology of the Academy of Sciences of the Czech Republic, Department of the History of Music of the Moravian Museum). Based on the presented facts, the paper attempts to incorporate the Brno musicology into wider context of present musicology and specifies the possible prospects for future development.

Key words

Czech, Musicology, Brno, University, institutions

\section{Bibliography}

POLEDŇÁK, Ivan - LÉBL, Vladimír a kol. Česká hudební věda po roce 1945. In Hudební věda I. Praha: SPN 1988, s. $235-264$.

MACEK, Petr. Postskriptum aneb Brněnská muzikologie v současnosti. In Macek, Petr - Pečman, Rudolf (eds.). Musicologia Brunensis. Ad honorem Jan Racek, Bohumir Štédroň et Zdeněk Blažek 1905 - 2005. Praha: KLP 2005, s. 235 - 238.

Webové stránky jednotlivých institucí:

www.phil.muni.cz/music

http://www.katedrahudebnivychovy.estranky.cz/

http://hf.jamu.cz/

http://www.imus.cz/

http://www.mzm.cz/oddeleni-dejin-hudby/ 
